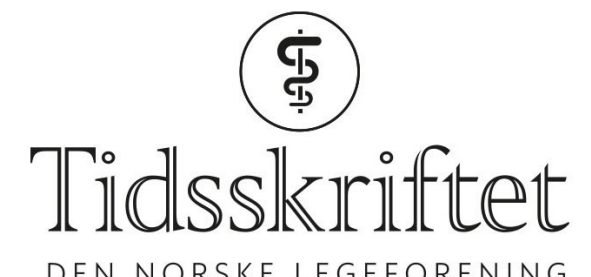

\title{
Ingen smal reise
}

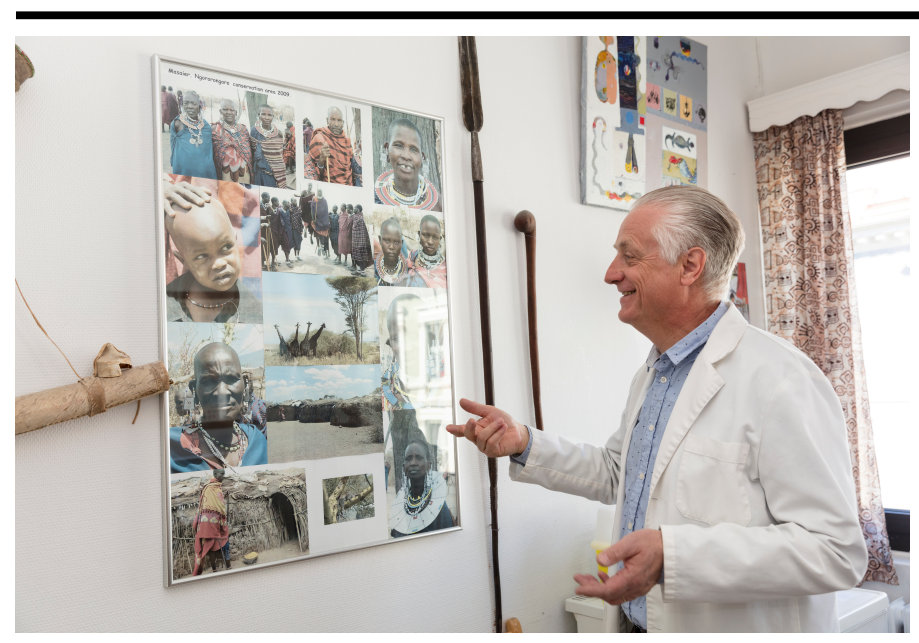

MITT FAGFELT

Gunnar Hasle er lege med en ph.d.-grad i zoologi. Han driver Reiseklinikken i Oslo og har reisemedisin som sitt fagområde.

- Reisemedisin kan i utgangspunktet høres smalt ut, men faget berører tropemedisin, villmarksmedisin, immunologi, fysiologi, epidemiologi, farlige dyr, medisinsk entomologi og alt som har med reisendes sikkerhet å gjøre, forteller Hasle.

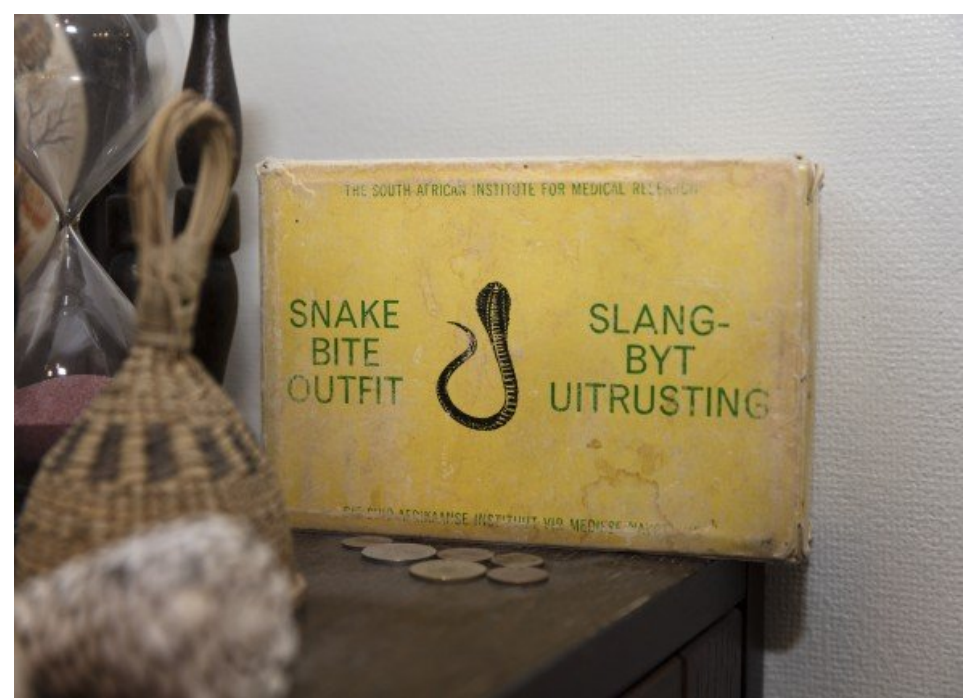

Kan du fortelle om noe viktig som skjer innenfor reisemedisin for tiden? 


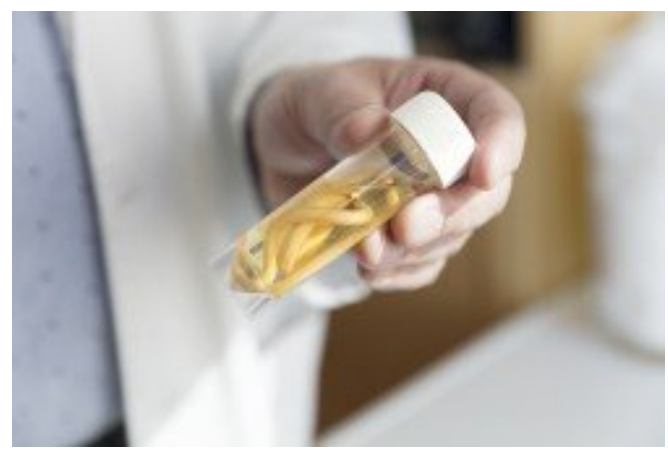

Nesten en tredel av dem som reiser til Afrika, Asia og Latin-Amerika får diaré. Vi har ikke hatt noen effektive måter å forebygge diaré på, annet enn ved å bruke antibiotikabehandling forebyggende - noe jeg håper at ingen norsk lege vil finne på. På Reiseklinikken har vi nylig gjort en randomisert klinisk studie av et forebyggende galaktooligosakkarid (B-GOS). Resultatene våre venter på å bli publisert. En tidligere studie viste både redusert insidens og varighet av diaré (1). US Army og Food and Drug Administration (FDA) holder nå på med en stor studie av dette stoffet på amerikanske soldater i utenlandstjeneste, og vi venter resultater fra denne studien om et års tid. Kanskje kan vi endelig få en miljøvennlig, billig og bivirkningsfri måte å forebygge diaré på.

Oligosakkarider er kjeder av 3-10 monosakkarider som ikke kan fordøyes av våre enzymer, men de kan være næring for diverse melkesyrebakterier og kan øke mengden av gunstige bakterier i tarmfloraen. Dette kalles en prebiotisk effekt (2). Morsmelk inneholder rikelig med galakto-oligosakkarider (GOS). Det er funnet at spedbarn som får morsmelk med høy konsentrasjon av oligosakkarider, har mindre diaré enn de som får morsmelk med lav konsentrasjon (3). En in vitro-studie viste at galakto-oligosakkarider hindret trofozoitter av Entamoeba histolytica i å feste seg til humane adenokarsinomceller (4). Muligens kan de binde seg til de patogene tarmbakterienes adhesiner og dermed hindre bakteriene i å invadere slimhinnene (5). En in vitro-studie viste at forebyggende behandling med galaktooligosakkarider reduserte invasjonen av Salmonella typhimurium i tarmceller fra mennesker og intakt tarmslimhinne fra mus (6). Det er også holdepunkter for at galaktooligosakkarider kan stimulere det medfødte immunforsvaret og IgA-sekresjonen i tarmen (7). Reiseklinikkens studie vil ikke alene løse problemet med turistdiaré, og det er et langt stykke frem til vi vet hvilke oligosakkarider eller hvilke kombinasjoner av dem som vil virke best. Og vi vet ikke nok om hvordan de virker eller hva slags diaré de virker på.

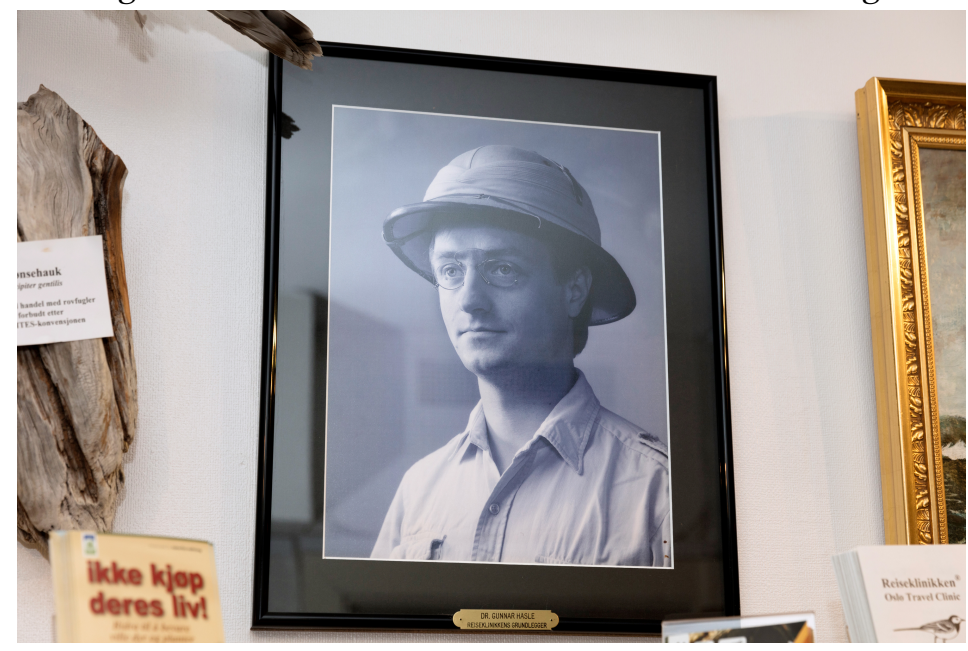

\section{Kan du anbefale en ny og interessant artikkel?}

En finsk gruppe testet avføringen til et stort antall reisende med polymerasekjedereaksjon (PCR) etter hjemkomst. De fant patogene tarmbakterier hos $61 \%$ av de friske og hos $83 \%$ av dem som hadde eller hadde hatt diaré (8). De med diaré hadde mye oftere flere patogener, oftest med Escherichia coli - enteroaggregative (EAEC), enteropatogene (EPEC), 
enterotoksiske (ETEC)- eller med Campylobacter. Denne studien utfordrer våre vante forestillinger om smitterisikoen for tarmpatogener.

\section{Hva er ditt favoritthjelpemiddel på jobb?}

Jeg bruker aktivt internasjonale reisemedisindatabaser, som Promedmail (www.promedmail.org/) og Travax (www.travax.nhs.uk/). Dessuten er et vanlig atlas et svært godt hjelpemiddel.

\section{LITTERATUR:}

1. Drakoularakou A, Tzortzis G, Rastall RA et al. A double-blind, placebo-controlled, randomized human study assessing the capacity of a novel galacto-oligosaccharide mixture in reducing travellers' diarrhoea. Eur J Clin Nutr 2010; 64:146 - 52.

2. Mussatto SI, Mancilha IM. Non-digestible oligosaccharides: A review. Carbohydr Polym 2007; 68: 587 -97 .

3. Morrow AL, Ruiz-Palacios GM, Altaye M et al. Human milk oligosaccharides are associated with protection against diarrhea in breast-fed infants. J Pediatr 2004; 145: 297-303.

4. Jantscher-Krenn E, Lauwaet T, Bliss LA et al. Human milk oligosaccharides reduce Entamoeba histolytica attachment and cytotoxicity in vitro. Br J Nutr 2012; 108: 1839 - 46.

5. Shoaf-Sweeney KD, Hutkins RW. Adherence, anti-adherence, and oligosaccharides preventing pathogens from sticking to the host. Adv Food Nutr Res 2009; 55:101 - 61.

6. Searle LEJ, Best A, Nunez A et al. A mixture containing galactooligosaccharide, produced by the enzymic activity of Bifidobacterium bifidum, reduces Salmonella enterica serovar Typhimurium infection in mice. J Med Microbiol 2009; 58:37-48.

7. Alizadeh A, Akbari P, Difilippo E et al. The piglet as a model for studying dietary components in infant diets: effects of galacto-oligosaccharides on intestinal functions. Br J Nutr 2016; 115: 605-18.

8. Lääveri T, Antikainen J, Pakkanen SH et al. Prospective study of pathogens in asymptomatic travellers and those with diarrhoea: aetiological agents revisited. Clin Microbiol Infect 2016; 22: 535 - 41.

Publisert: 26. juni 2017. Tidsskr Nor Legeforen. DOI: 10.4045/tidsskr.17.0403

(C) Tidsskrift for Den norske legeforening 2020. Lastet ned fra tidsskriftet.no 